\title{
The Effect of Attachment Styles on Perfectionism in Romantic Relationships
}

\author{
Yağmur Çerkez \\ Near East University, Nicoisa, NORTH CYPRUS
}

Received 11 May 2017 • Revised 6 August 2017 • Accepted 16 September 2017

\begin{abstract}
The aim of this study was to examine the effect of attachment styles on perfectionism in romantic relationships among university students. 136 university students participated in this study. The data collection tools were "Perfectionism in Romantic Relationships Scale" and "Relationships Scale". The ANOVA analysis system was used to define the differences, if any, in points related to the participants' and their partners' gender, birthsequence, the state of their relationships, and attachment. A correlation analysis to with age was carried out to determine differences, if any, to do with age and a t-test analysis was used to determine differences, if any, to do with gender. The findings showed that there was no difference in terms of gender in both perfectionism type scores. In addition, while there were no differences in self-perfectionism scores according to their birthsequence, there are reasonable differences when romantic relationships are at stake. A posthoc study showed that these differences are seen among the participants with no past experience, but have newly started a relationship. When points related to a partner's perfectionism is considered, it is seen that there are no differences to do with birthsequence and romantic relationships. A negative correlation, at a reasonable level, has been seen between age and partner-oriented perfectionism. Finally, there seemed no differences between self-perfectionism and partner's perfectionism points in attachment styles.
\end{abstract}

Keywords: perfectionism, attachment styles, university students, relationships

\section{INTRODUCTION}

For many individuals, having a close, positive and effective relationship means happiness, enjoying life and feeling confident. For Sternberg (1986), maintaining long-lasting friendship and self-development without any problems shows mutual communication and understanding which form emotional attachment between couples. Gizir (2012) points out that the quality of intimacy among individuals affects their mental development, self-respect, success and social adaptation. Romantic relationships in the scope of close relationships are defined as a relationship as a result of attachment and passion and is considered as the most important psychological development in puberty age (Sternberg (1986; Erikson, 1968).

Like other intimate relationships, romantic relationships affect individuals' social, emotional and personal development as well as forming the quality of the relationship between families and friends (Gizir, 2012). Intimate relationships are more important compared to other stages for young adults because at this stage they try to develop their roles. Furman (2002) points out that romantic relationships at university years help them in choosing their spouses as well as the quality of other relationships.

(C) Authors. Terms and conditions of Creative Commons Attribution 4.0 International (CC BY 4.0) apply. Correspondence: Yağmur Çerkez, Near East University, Faculty of Education, Department of Psychological Counseling and Guidance, Nicoisa, North Cyprus. Phone: 00905338672262 


\section{State of the literature}

- When the studies on the subject-matter is considered, it is strongly emphasized that university students consult most frequently to the Psychological Guidance Centers with problems and disagreements they experience in their relationships (Tütküm, Kızıltaş and Sarıyer, 2004; Creasy and Ladd, 2004; Küçükarslan, 2011).

- Whereas in national and international literature, it is noted that married individuals focus on their beliefs in relationships (Küçükarslan, 2011; Hazan \& Shaver, 1994).

\section{Contribution of this paper to the literature}

- It will contribute to the literature on perfectionism in romantic relationships.

- It will provide suggestions for solving the current issues of university students' lives.

- It will contribute to the literature of the studies carried out in small countries.

Research studies show that, first romantic experiences at young ages play a great role in the development of intimate relationships at later ages (Q'sullivan, Cheng, Harris and Brooks-Gunn, 2007; Davies, 2006; Raley and Sullivan, 2010). Particularly research on romantic relationships among university students show that such relationships occupy a great time in their lives (Demir, 2008) and an average of $\% 65$ of them experience a romantic relationship at least once at university years (Collins, 2003).

The concept of perfectionism and parent-child relationship (Flett, Hewitt, Oliver\& McDonalds, 2002; Kenny Benson \& Pomerantz, 2005), mutual relationships among individuals (Besharat, 2004; Larijani \& Besharat, 2010; Stoeber, 2013) and romantic relationships (Flett, Hewitt, Shapiro \& Rayman, 2001; Makinnon, Sherry, Antony, Stewart \& Sherry, 2012; Stoeber, 2012) have been dealt with in many studies. Although the researchers did not agree on a clear definition of the concept of perfectionism, in many resources it is assumed that it is the major focus on an individual's efforts in specifying high personal standards and perfectionism (Frost, Marten, Lahart \& Rosenblate, 1990; Flett \& Hewitt, 2002).

In their studies, Hewitt and Flett (1991) looked at perfectionism through various angles among groups and individuals and specified it as based on "self-oriented", "others-oriented", and "social oriented". At this point, perfectionism was examined according to what was expected from others (Flett \& Hewitt, 2002). In self-related perfectionism, the bases of one's behaviors are the individual himself/herself. In this regard, the individual sets unrealistic high standards for himself/herself, criticizes weaknesses heavily and tries to generalize his thoughts to his behaviors. On the other hand, in perfectionism to do with others, various elements were dealt with and it was seen that the individual sets unrealistic standards, exhibits excessive evaluating approaches, and refrains from failure, but even at this point, the focus is on others. Finally, in the case of social perfectionism, individuals are preoccupied with the idea that others set high standards and evaluate them in the light of those standards (Hewitt \& Flett, 1991).

Flett et al. (2001) developed a model in which they studied perfectionism in romantic relationships in two dimensions; perfectionism towards others - developing strict standards towards the partner and perfectionism for oneself - strict standards towards self-behavior. Similarly, Wiebe and McCabe (2002) examined the same issue in two dimensions; over-strict standards for oneself and partner's conception of over-strict standards and developed the scale of perfectionism in relationships. Stoeber, (2012), too, examined the issue in two dimensions; self overstrict standards and over-strict standards perceived from partners. In their study on the Turkish adaptation of perfectionism in individual romantic relationship, Özteke, Büyükbayraktar and Kesici (2015) explained perfectionism as self-oriented perfectionism and perfectionism towards partners. This present study deals with these dimensions in perfectionism in romantic relationships.

In studies and literature related to relationships between people, the concept of "attachment" was considered to be the one of the effective theory (Kuyumcu, 2011). In the theory of attachment behavior in babies, John Bowlby points out the theory as a strong bond by people towards the others they consider as important (Bowlby, 1969). Bowlby (1982) and Ainsworth (1989) classified attachment styles in babies in three different styles 
as safe, unsafe-anxious, and unsafe- side-step attachment. Later, Bartholomew and Horowitz (1991), based on these studies, divided attachment among grown-ups into four styles; safe-attachment, dismissive avoidant-attachment, preoccupied-attachment, and insecure-attachment. In the light of these points, attachment styles are effective roles in individuals 'intimate behaviors, the degree of influence they face in, the rate of satisfaction, and overcoming such situations in relationships (Gonzaga, 2001).

Secure-attachment style is defined as a positive ego and values, which includes low rate anxiety and low rate avoidance. Individuals in this style have a positive ego conception and they are comfortable in close relationships. Even more, such individuals see others as reliable, easy to reach, supportive and good willing and they have both the feeling of positive ego and self-appreciation. Therefore, individuals with the ability of secureattachment are both autonomous and can establish long-lasting positive relationships with others (Bartholomew, 1994).

In preoccupied-attachment styles, while others are perceived positively, one's ego is perceived negatively and in such a style, anxiety level is high and avoidance level is low. In the case of such a style, the individuals lack self-esteem, feel insignificant, look at others positively and exhibit high efforts to prove themselves. Even more, in intimate relationships they have unrealistic expectations and reflect preoccupied behaviors (Bartholomew, 1994).

In an insecure-attachment style, one perceives both himself and others negatively. In this style, anxiety and avoidance rates are high. These individuals have negative expectations from others and try to refrain from being refused and being the loser (Griffin \& Bartholomew, 1994). Such individuals do not only blame their spouses for not being sincere, but they focus on them and develop an ongoing control mechanism over their spouses.

Finally, in a dismissive avoidant attachment style, one perceives his ego positively, but perceives others negatively. In such a situation, both, high anxiety and avoidance level is at stake. Because such individuals have negative expectations, they refrain from establishing good relationships. They emphasize the importance of freedom and adapt a feeling of autonomy, ignoring the possibility of being on their own. They do not trust their spouses in their romantic relationships (Feeny, 2002). Therefore, they try to minimize the rate of their feelings and intimacy in their relationships (Riggs, Jacobvitz \& Hazen, 2002).

In studies dealing with romantic relationships, it has been noticed that the utmost attention was on nonfunctional beliefs and their effects on romantic relationships (Epstein, 1986; Eidelson and Epstein, 1982). According to this, as the non-functional beliefs increase, individuals focus more on the negative sides of their spouses, which may put an end to their romantic relationships (Medora, Larson, Hortaçsu, and Dave, 2002; James, Hunsley and Hemsworth, 2002).

Sherry, Sherry, Mcneil, Smith and Mackinnon (2014) studied clashes and perfectionism in romantic relationships and emphasized that self or partner-oriented perfectionism was a factor in clashes. Similarly, Makkinon et al. (2012) argued that perfectionist thoughts underlined clashes and depression symptoms. In another study by Stoeber (2012), partner-oriented perfectionism has a negative effect on self-satisfaction in relationships and long-lasting attachment. All these findings indicate that perfectionism in romantic relationships plays a great role on the quality of relationship, satisfaction and some psychological symptoms.

Studies carried out show that there is a connection between attachment-styles, psychological symptoms and mental functions. For example, Lippe Von der Eilersten, Hartmann and Kille (2010), point out that children from secure-attachment-style mothers develop the same style and their mental functions are affected positively. On the other hand, according to Cabeldue and Boswell (2012), timid and anxious styles affect individuals in their selfefficiency beliefs negatively. In another study carried out in Turkey, Vatan (2015), examined the relation between preoccupied and compulsive indications and found out that attachment dimensions constrained preoccupied beliefs. 


\section{METHODS}

\section{Research Design}

This is a descriptive study in which relationships are researched. The dependent variable of the study is perfectionism and the independent variables are secure-attachment, insecure-attachment, dismissive avoidantattachment, and preoccupied-attachment with gender, age, birth-sequence, and the state of romantic relationships.

\section{Participants}

This study extends its scope to university students, 136 of whom were picked through random sampling as participants.

\section{Data Collection Tools}

\section{Perfectionism in romantic relationships scale}

A scale was developed by Matte and LaFontaine (2012) to specify the participants' perfectionism in romantic relationships. A Turkish version of the form, adapted in a study in 2015 by Özteke, Girgin, Büyükbayraktar, and Kesici, was used in this study. Both forms, Turkish and English, were used in a two-week interval and the translation was found to match the original. The participants were those university students with a romantic relationship for more than 12 months. The reliability level of both forms (Turkish and English) was high $(r=91, p<0.01)$. Although the scale consisted of 14 items according to the result of the confirming factor analysis, it came out in two items as in the original form as; self-oriented perfectionism $(1,2,3,4,5$, 6, and 7) and partneroriented perfectionism $(8,9,10,11,12,13$, and 14). Item $6,10,11$, and 13 were marked reversely. Any high point in the lower dimension refers high level perfectionism. The correlation of total items is between 30 and 70 which equals to 76 in Cronbach alpha value.

\section{Relationship scales questionnaire}

Attachment styles of the participants were defined through a 30-item relationship- scale questionnaire (RSQ) developed by Griffin and Bartholomew (1994). The relationship scales were composed of Hazan's and Shaver's (1987) attachment-scale paragraphs and from Bartholomew's and Horowitz's (1990) items they used in relationship questionnaires. 18 items were used in this study. Attachment styles were specified with the points from 18 items related to four attachment-styles (Güngör, 2000). The participants evaluated on a seven-step scale $(1=$ It doesn't define me; $7=$ It clearly defines me). Secure $(3,7,8,10,17)$ and dismissive avoidant $(2,5,12,13,16)$ attachment-styles were evaluated in four items; preoccupied $(6,11,15,18)$ and insecure- attachment $(1,4,9,14)$ styles were evaluated in four items. The participants' replacement in one of the four attachment styles was based on their highest scores.

In the translation of the scale into Turkish, a translation - retranslation method was used (Sümer \& Güngör, 1999). The English version of the form was translated into Turkish by four experts in the field. The Turkish form agreed on was translated into English. The scale was finalized after some comparisons were done. In their study on the reliability and validity of the Turkish sampling, Sümer and Güngör (1991) referred to psychometric features of the Relationship Scales questionnaire. It was noted in the study that the coefficiency inter-validity of the Scales varied between .27 and .61 (Sümer \& Güngör, 1999).

\section{Personal information form}

In the Personal Information form, developed by the researcher, the participants were asked to state their gender, age, and birth-sequence and the state of their relationships. 
Table 1. Demographic peculiarities of the participants

\begin{tabular}{lll}
\hline & Frequency & Percentage \\
\hline Gender & & 55.1 \\
\hline Female & 75 & 44.9 \\
\hline Male & 61 & \\
\hline Birth sequence & & 41.9 \\
\hline First child & 57 & 30.1 \\
\hline Second child & 41 & 11.0 \\
\hline Third child & 15 & 16.9 \\
\hline Fourth and later & \\
\hline The state of romantic relationship & 19.9 \\
\hline I had never experienced it before, but now I am experiencing it & 31.6 \\
\hline I had experienced before it, but I am not experiencing it now & 23 & 26.5 \\
\hline I had experienced before and I am experiencing it now & 27 & 22.1 \\
\hline I have never experienced it & 43 & \\
\hline Perfectionism & 36 & 71.3 \\
\hline Self-oriented perfectionism & 30 & 28.7 \\
\hline Partner-oriented perfectionism & & \\
\hline Attachment styles & 97 & 25.7 \\
\hline Secure & 39 & 47.1 \\
\hline Dismissive avoidant & & 19.9 \\
\hline Preoccupied & 35 & 7.4 \\
\hline Insecure & 64 & SDerage \\
\hline Age & 27 & 22.52 \\
\hline
\end{tabular}

\section{Data Analysis and Procedure}

After getting the permission from the University Administration to carry out the study, the data was collected while the participants were in class. The data collected was overviewed for any mistakes and unanswered questions. Then the analysis was done on fully completed data sets. Data analysis was carried out through the 20th version of the SPSS program. A t-test was applied to define the effect of gender on the perfectionism in romantic relationships and ANOVA analysis, a correlation analysis was applied to examine the relation between age and perfectionism, and, once more, ANOVA analysis was applied to examine the relation between perfectionism and attachment-styles in romantic relationships.

\section{FINDINGS AND DISCUSSIONS}

All demographic information about the subject-matter in question is shown in Table 1. According to the findings, $75(55.1 \%)$ of the participants in $22.52(\mathrm{SD}=2.5)$ age-average are female and $61(44.1 \%)$ male. When their birth-sequence is considered, $41.9 \%$ of them are the first child, $30.1 \%$ are the second, $11 \%$ are the third, and $16.9 \%$ are the fourth or later. In the case of romantic relationships, it was found out that $19.9 \%$ of the participants had never experienced a relationship before, but at present they are experiencing it. On the other hand, $31.6 \%$ of them had experienced a relationship before, but at present they are without it. Even more, $26.5 \%$ of the participants had experienced a relationship before and they are still experiencing it at present. Finally, $22.1 \%$ of them have never experienced a relationship up to the present.

From the perfectionism scores, it is noted that $71.3 \%$ of the participants are in self-oriented, and $28.7 \%$ of them are in partner-oriented classification. In addition, $25.7 \%$ are in secure style, $47.1 \%$ are dismissive avoidant, $19.9 \%$ are in preoccupied, and $7.4 \%$ are insecure-attachment style. A t-test was applied to define any differences by 
Y. Çerkez / Perfectionism in Romantic Relationships

Table 2. T-test table showing the differences by gender in the level of perfectionism

\begin{tabular}{llllll}
\hline & N & Average & t & df & P \\
\hline Self-oriented perfectionism & & & & & \\
\hline Female & 75 & 32.61 & -.651 & 134 & .516 \\
\hline Male & 61 & 33.40 & & & \\
\hline Partner-oriented perfectionism & & & & & \\
\hline Female & 75 & 28.44 & .232 & 134 & .817 \\
\hline Male & 61 & 28.22 & & & \\
\hline
\end{tabular}

Table 3. Correlation analysis results related to the relation between age and perfectionism scores

\begin{tabular}{lll}
\hline & $r$ & $\mathrm{P}$ \\
\hline Self-oriented perfectionism & -.023 & .795 \\
\hline Partner-oriented perfectionism & -.180 & $.036^{*}$ \\
\hline
\end{tabular}

Table 4. ANOVA analysis results to define differences (if any) in perfectionism scores related to attachment styles

\begin{tabular}{lccccc}
\hline & Sum of Squares & df & Mean Squares & F & P \\
\hline Self-oriented perfectionism & & & & & \\
\hline Between groups & 31.89 & 3 & 10.63 & 208 & .891 \\
\hline Within groups & 6737.99 & 132 & 51.04 & & \\
\hline Partner-oriented perfectionism & & & & & \\
\hline Between groups & 143.70 & 3 & 47.90 & 1.766 & .157 \\
\hline Within groups & 3581.05 & 132 & 27.12 & & \\
\hline
\end{tabular}

gender on either self-oriented or partner-oriented perfectionism scores. Table 2 shows that there are no differences in perfectionism scores by gender $(\mathrm{p}<0.05)$.

ANOVA analyses were done to identify the effect of birth- sequence and the state of relationship of the participants on perfectionism points (Table 3). The results of the analysis showed that, while there were no differences in self-oriented perfectionism scores related to birth-sequence $(F(3,132)=.805, p<0.05)$, there were reasonable differences in romantic relationships $(F(3,132)=6.899, p<0.001)$. In order to see the reasonable differences between types of relationships, a post-hoc test was applied.

The result of the test showed that, the difference was between participants with no previous experience and the ones experiencing a relationship now $(\mathrm{p}<0.001)$. Even more, participants with no previous experience, but experiencing it now have higher self-oriented perfectionism scores compared to the other group. According to these values, in the results with Cohen's d value 1.088, the effect rate was 0.47 . When partner-oriented perfectionism scores were examined, there seemed no differences related to birth-sequence $(F(3,132)=1.478 ; p<0.05)$ and the state of romantic relationships $(\mathrm{F}(3,132)=2.480, \mathrm{p}<0.05)$.

A final ANOVA analysis was done to define differences (if any) between perfectionism scores and attachment styles (See Table 4). The analysis showed that there were no differences between self-oriented perfectionism scores $(\mathrm{F}(3,132)=.208, \mathrm{p}<0.05)$ and partner-oriented perfectionism scores $(\mathrm{F}(3,132)=1.766, \mathrm{p}<0.05)$ (Table 4).

\section{CONCLUSION AND SUGGESTIONS}

The aim of this study was to define the effect of attachment styles on perfectionism in romantic relationships among university students. The findings show that there are no differences in self-oriented or partneroriented scores related to gender. This is an indication that gender does not have any effect on perfectionism in romantic relationships. 
Moreover, while there are no differences in scores related to self-oriented perfectionism according to birthsequence, there seemed reasonable differences when romantic relationships are at stake. A post-hoc test showed that this difference seemed between individuals with no romantic relationship in the apast, but experiencing it now which indicates a lower level of self-oriented perfectionism between inexperienced individuals and individuals experiencing it now. This can be interpreted as that individuals' expectations are high in their self-oriented romantic relationships.

It is also noted that, there is a reasonable difference between birth-sequence and the state of relationship when partner-oriented perfectionism scores are examined.

Finally, differences were noted in self-oriented and partner-oriented perfectionism scores according to attachment styles. However, these findings do not match with previous research findings. For example, Vatan (2015) investigated the relation between preoccupied and compulsive signs related to attachment styles and found out that attachment styles dimensions affected preoccupied beliefs. The present study deals only with perfectionism in romantic relationships and attachment styles are considered as ineffective factors. If a future study on the same subject is done with a larger sample, findings will be more comprehensible.

\section{REFERENCES}

Ainsworth, M. D. S. (1989). Attachment beyond infancy. American Psychologist, 44(4), 709-716.

Bartholomew, K. (1990). Avoidance of intimacy: an attachment perspective. Journal of Social and Personal Relationships, 7, 147-178.

Besharat, M. A. (2004). Perfectionism and interpersonal problems. Daneshvar Raftar, 11(7), 1.

Bowlby, J. (1969). Attachment and loss: Attachment. New York: Basic Books.

Bowlby, J. (1982). Attachment and loss: Retrospect and prospect. American Journal of Orthopsychiatry, 52, 664-678.

Cabeldue, M., \& Boswell, S. S. (2012). Predictors of relationship self-efficacy in undergraduates. Psi Chi Journal of Psychological Research, 17(4), 154-162.

Collins, W. A. (2003). More than myth: The developmental significance of romantic relationship during adolescence. Journal of Reserach of Adolescence, 13, 1-24.

Creasey, G., \& Ladd, A. (2004). Negative mood regulation expectancies and conflict behaviors in late adolescent college student romantic relationships: The moderating role of generalized attachment representations. Journal of Research on Adolescence, 14(2), 235-255.

Davies, M. F. (2006). Irrational beliefs and unconditional self-acceptance. I. Correlational evidence linking two key features of REBT. Journal of Rational-Emotive and Cognitive-Behavior Therapy, 24(2), 113-124.

Demir, M. (2008). Sweetheart, you really make me happy: Romantic relationship quality and personality as predictors of happiness among emerging adults. Journal of Happiness Studies, 9, 57-277.

Eidelson, R. J., \& Epstein, N. (1982). Cognition and relationship maladjustment: Development of a measure of dysfunctional relationship beliefs. Journal of Consulting and ClinicalPsychology, 50, 715-720.

Epstein, N., \& Eidelson, R. (1981). Unrealistic beliefs of clinical couples: Their relationship to expectations, goals and satisfaction. American Journal of Family Therapy, 9, 13-22.

Erikson, E. (1968). Identity: Youth and Crisis. New York: W. W. Norton \& Company Inc.

Feeney, J. (2002). Attachment, marital interaction and relationships satisfaction: A diary study. Personal Relationships, 9(1), 39-55.

Flett, G. L., \& Hewitt, P. L. (2002). Perfectionism and maladjustment: An overview of theoretical, definitional, and treatment issues. In: Gordon L Flett, Paul L Hewitt (Eds.): Perfectionism: Theory, Research, and Treatment. Washington, DC: American Psychological Association, 5-31.

Flett, G. L., Hewitt, P. L., Shapiro, B., \& Rayman, J. (2001). Perfectionism, beliefs, and adjustment in dating relationships. Current Psychology, 20(4), 289-311. 
Flett, G.L., Hewitt, P. L., Oliver, J. M., \& Macdonald, S. (2002). Perfectionism in children and their parents: A developmental analysis. In: Gordon L Flett, Paul L Hewitt (Eds): Perfectionism: Theory, Research, and Treatment. Washington, DC: American Psychological Association, 89-132.

Frost, R. O., Marten, P., Lahart, C., \& Rosenblate, R. (1990). The dimensions of perfectionism.Cognitive Therapy and Research, 14(5), 449-468.

Furman, W. (2002). The emerging field of adolescent romantic relationships. Current Directions in Psychological Science, 11, 177-180.

Gizir, C. A. (2012). İlişki İnançları Ölçeği'nin Uyarlanması: Geçerlik ve Güvenirlik Çalışmaları. Mersin Üniversitesi Ĕ̆itim Fakültesi Dergisi, 8(2), 37-45.

Gizir, C. A. (2013). Üniversite Öğrencilerinin İlişki İnançlarının Cinsiyet ve Romantik İlişki Yaşama Durumlarına Göre İncelenmesi. Eğitim ve Bilim, 38(170), 372-383.

Gonzaga, C. (2001). Love and the commitment problem in romantic relations and friendship. Journal of Personality and Social Psychology, 81(4), 247-262.

Güngör, D. (2000). Bağlanma stillerinin ve zihinsel modellerin kuşaklara aktarımında ana-babalık stillerinin rolü. Ankara: Ankara Üniversitesi Sosyal Bilimler Enstitüsü (Unpublished Doctoral Thesis).

Hazan, C., \& Shaver, P. R. (1994). Attachment as an organizational framework for research on close relationships. Psychological Inquiry, 1, 1-22.

James, S., Hunsley, J., \& Hemsworth, D. (2002). Factor structure of the relationship belief inventory. Cognitive Therapy and Research, 26(6), 729-744.

Kenney Benson, G. A., \& Pomerantz, E. M. (2005). The role of mothers' use of control in children's perfectionism: Implications for the development of children's depressive symptoms. Journal of Personality, 73(1), 23-46.

Kuyumcu, B. (2011). Evli Kişilerde Gestalt Temas Biçimleri ve Bağlanma Stilleri Arasındaki İlişkinin İncelenmesi. M. Akif Ersoy Üniversitesi Sosyal Bilimler Enstitüsü Dergisi, 3, 57-70.

Küçükarslan, M. (2011). Mersin Üniversitesi Öğrencilerinin Romantik İlişkilere Yönelik İnançlarının Cinsiyet, Sınıf Ve Romantik İlişki Yaşama Durumu Değişkenlerine Göre İncelenmesi (Unpublished Masters thesis). Mersin Üniversitesi, Eğitim Bilimleri Enstitüsü, Mersin.

Larijani, R., \& Besharat, M. A. (2010). Perfectionism and coping styles with stress. Procedia-Social and Behavioral Sciences, 5, 623-627.

Lippe, A., Von Der Eilertsen, D. A., Hartmann, E., \& Kille, K. (2010). The role of maternal attachment in children's attachment and cognitive executive functioning: A preliminary study. Attachment $\mathcal{E}$ Human Development, 12(5), 429-444.

Mackinnon, S. P., Sherry, S. B., Antony, M. M., Stewart, S. H., \& Sherry, D. L. (2012). Caught in a bad romance: Perfectionism, conflict, and depression in romantic relationships. Journal of Family Psychology, 26(2), 215.

Medora, N. P., Larson, J. H., Hortaçsu, N., \& Dave, P. (2002). Perceived attitudes towards romanticism: A crosscultural study of American, Asian-Indian and Turkish young adults. Journal of Comparative Family Studies, $35(2), 155-76$.

Özteke, H. İ., Girgin, Ç., Büyükbayraktar, C. G., \& Kesici, Ş. (2015). The adaptation of Romantic Relationship Scale into Turkish Culture. Anthropologist, 19(1), 387-395.

Q'sullivan, F. C., Cheng, M. M., Harris, M. H., \& Brooks-Gunn, J. (2007). I wanna hold your hand: The progression of social, romantic and sexual events in adolescent relationships. Perspectives on Sexual and Reproductive Health, 39(2), 100-107.

Raley, R. K., \& Sullivan, M. K. (2010). Social-contextual influences on adolescent romantic involvement: The constarnints of being a numerical minority. Sociological Spectrum, 30, 65-89.

Riggs, A., Jacobovitz, D., \& Hazen, N. (2002). Adult attachment and history of psychotherapy in a normative sample. Psychotherapy: Theory, Research, Practice, Training, 39(4), 344-353.

Sherry, S. B., Sherry, D. L., Macneil, M. A., Smith, M. M., \& Mackinnon, S. P. (2014). Does socially prescribed perfectionism predic daily conflict? A 14-day daily diary study of romantic couples using self and partner reports. Personality and Individual Differences, 61, 24-27. 
Silver, D. H. (1992). Working models of childhood attachment and couple relationships. Journal of Family Issues, $13(4), 432-450$.

Sternberg, R. J. (1986). A triangular theory of love. Psychological Review, 93(2), 119-135.

Stoeber, J. (2012). Dyadic perfectionism in romantic relationships: Predicting relationship satisfaction andlong-term commitment. Personality and Individual Differences, 53(3), 300-305.

Stoeber, J. (2014). How other-oriented perfectionism differs from self-oriented and socially prescribed perfectionism. Journal of Psychopathology and Behavioral Assessment, 36(2), 329-338.

Sümer, N., \& Güngör, D. (1999). Yetişkin bağlanma stilleri ölçeklerinin Türk örneklemi üzerinde psikometrik değerlendirmesi ve kültürler arası bir karşılaştırma. Türk Psikoloji Dergisi, 14(43), 71-106.

Türküm, S. A., Kızıltaş, A., \& Sarıyer, A. (2004). Anadolu Üniversitesi Psikolojik Danışma ve Rehberlik Merkezi'nin Hedef Kitlesinin Psikolojik İhtiyaçlarına İlişkin Ön Çalışma. Türk Psikolojik Danışma ve Rehberlik Dergisi, 3, 15-29.

Vatan, S. (2015). Investigating the mediator roles of obsessive beliefs in the relationships between, attachment and obsessive compulsive symptoms. Anadolu Psikiyatri Dergisi, 16(3), 155-163.

Wiebe, R. E., \& McCabe, S. B. (2002). Relationship perfectionism, dysphoria, and hostile iterpersonal behaviors. Journal of Social and Clinical Psychology, 21(1), 67-91.

\section{http://www.ejmste.com}

